understanding of physiology and pathology to clinical and operative problems is of much greater moment. In general the successful surgeon should possess robust health, energy, and ability to make decisions under circumstances of stress. A measure of philosophic doubt is desirable together with a critical faculty which extends its operation to his own actions. I think a certain degree of optimism is an asset if a man is to remain undismayed and not discouraged by the occasional but inevitable failures in his work. Some seem to have developed an intuitive judgment-perhaps a natural endowment, but also supported by the fruits of observation and criticism of past results. Joseph Conrad, in a generalization, gives, I think, a good picture of what is in my mind. "I don't mean the courage of self-assertion, either moral or physical, but the mere way of it, the trick of the thing, the readiness of mind and the turn of the hand that come without reflection and lead the man to excellence in life, in art, in crime, in virtue, and for the matter of that even in love."

So much for the characteristics which may help to form a surgeon. Surgery itself is no longer a compact section of medicine, though its position remains the same as the French surgeon-pathologist Bichat defined it 150 years ago: " La chirurgie est immense, elle emprunte à la médecine tous ses grands précepts, ou plutôt elle les partage en "commun avec elle, car l'art de guérir est un tronc. dont la médecine et la chirurgie sont les branches; partout les branches entrelacent leurs rameaux, elles se confondent." The process of fission has been a gradual one, but has now extended so far that the general surgeon in the old-fashioned sense is a rarity: we are all driven to specialize in some degree. Still, the basic training does not change; all specialties are governed by the same physiolog:cal and pathological knowledge, and no sections form watertight compartments. Technical complications and devalopments have imposed segregation on such branches as neuro- and genito-urinary surgery, and the thoracic field is perhaps the latest to qualify. The oldest and simplest part of surgery, that dealing with trauma, is tending to become segregated under the incongruous title " orthopaedic." However, complete specialization in any field does not usually come early in the training period, and often enough depends on the chance of openings rather than on any special aptitude of the aspirant.

\section{The National Health Service}

It is perhaps early to assess the effects of the National Health Service organization on surgical practice; it is certainly premature to pass judgment on it. That some such change in the organization of medicine was inevitable has been clear for many years. First, it is a tribute to the effective progress of medicine as a whole, which now offers service of inescapable value to the community. Secondly, the increase in cost of this service has been so great that the poorer members could not fully benefit from it unless the burden was supported by the State. So far as it influences the training and work of surgeons the new scheme has effected a dramatic change in the former so far as it is affected by financial considerations. When I was at hospital the house officer of a teaching hospital was unpaid and the registrars received from two to three hundred a year-lodging and keep were free. Now a man can get a living wage almost as soon as he is qualified, and from then on the scale rises liberally. The chanzes of obtaining consultant appointments have, I believe, altered little; although at the moment the balance of men in training against probable vacancies is awry. On the financial side the surgeon can still make a good income, although the amount derived from private practice is likely to diminish. In the old days, though some surgeons made much money the majority did not. The position of the man who takes a whole-time post has been greatly improved by the current system. Anyway, no branch of medicine should be estimated on its money-making possibilities; it remains a profession and not a trade.

How far bureaucratic control is likely to creep in is difficult to estimate. Medical representation on all effective committees is fair and can, I think, maintain the freedom of the profession. The essential work of the surgeon and his responsibility to his patients and the craft remain unimpaired. Though medicine is at present in the van of the advance, surgery is very much alive, and I think offers an attractive and rewarding way of life for those suitably equipped for its pursuit.

\section{PRIVATE PRACTICE}

BY

\section{LINDSEY W. BATTEN, M.B., M.R.C.P. Hampstead, London}

Picking me out as, I suppose, an elderly urban practitioner-a sort of ageing mariner - the Editor asked me to look back and tell him about my voyage. Why did I undertake it? Did I sail or drift? What winds and tides influenced my course? How has the trip worked out? What have I to say to intending adventurers? I think I neither sailed nor drifted but walked, guided by a sense of direction rather than following a goal, avoiding main roads but using tracks and paths that seemed to be going my way, getting to nowhere very special but seeing some good country and enjoying the walk. The ground I trod has been so changed that I doubt if any young traveller can follow, even roughly, the same route, which diminishes the practical value of my story. I cannot present myself as an example either to follow or to shun, but the tale may provide something to think about, and, since it is asked for, here it is.

\section{Choice of Career}

One summer holiday evening when I was rising 17 my father said it was time to decide what I wanted to be. We had some discussion, but I never thought seriously of being anything but a doctor. I thought, boylike, it would be fun to learn the physical sciences; more wisely, I thought I should be joining a great and high profession; no doubt I liked the idea of being of some use to my fellow men; but far more definitely and warmly I wished to follow the family traditions. Ancestor worship, à la chinoise, is a very powerful and enduring influence.

To-day a boy rash enough to opt for medicine at 16 seldom has any choice but to plant himself on that long, narrow educational ladder that leads to qualification. $\mathrm{He}$ is assumed to have "joined the science side." Forty years ago it was still not rare to continue a classical education with medicine in view, and I did so. A smattering of physics was added as a sop to Aesculapius. I cannot say how often I bless my parents, my teachers, and the 
kind Fates for those two last years of literae humaniores at school. I am sure there is no better preparation for the study of science or the practice of medicine.

Eight summers later I was within sight of qualifying. Besides the two industrious years at school, I had enjoyed three, less industrious but superlatively happy, at an ancient university and three, both industrious and happy, at a London teaching hospital. Chemistry and physics, on closer acquaintance, were scarcely the glamorous creatures they had seemed, glimpsed through the crack of the laboratory door, but biology and physiology made amends. Anatomy, once one got down to it, London fashion, was not unattractive, and the clinical arts were as fascinating at the first encounter as they have remained ever since. I had discovered, with surprise, that I found medicine more exciting than surgery, but I doubt if I pictured myself as a budding physician. I was to take the conjoint in stages next year, hope for a house job, attempt an M.B., and then think. Plans went no further.

Meantime life was busy and happy and the world very good. It seemed to us to be at once stable at bottom and in a state of delightful and beneficent flux and ferment on top. But this was July, 1914, and we were wrong about the stability. No plans withstood, even for a week, the impact of that sudden war. No one really conducted "business as usual." Students, teachers, even examiners (I must presume) felt the fervour of the hour, and by October I was qualified-a premature medical man.

\section{Wartime Experience}

I shed a little, but only a little, of my lanugo as one of two "medical receiving officers"-wartime creations -at my hospital and then "joined up." In the next four years those in authority, I myself, and the Fates, acting more or less in concert, really determined my medical future. The war took its appointed course and I cannot remember being asked very often what I wanted to do in it. But had I pressed for it I feel sure I could have spent at least some time in hospitals and C.C.S.s practising medicine, gaining clinical experience, perhaps even advancing in status. I thought medical soldiering the better life, and the authorities seemed not to think a lad of brilliant promise was being wasted "up the line," so I spent my time among fighting units and field ambulances. By the end of the war I had lost more lanugo ; I knew something of men, health, and hygiene ; a near-mortal illness had taught me a bit about nursing and how the patient sees it ; and I knew more than I had about myself, but of medicine, surgery, and pathology, to say nothing of obstetrics, I knew far less than I had known four years earlier.

To cap it all, being demobilized, I married and wrote off, in my own mind, whatever faint aspirings to consultant rank I could find there. They were faint enough. I think I have always liked all-roundness and the allrounder better than specialism and the specialist, and I have never felt the lure of the rare. Given the appropriate qualities of hand, mind, or intellect I can imagine wanting to be, for example, a surgeon or a neurologist or becoming enamoured of, say, ophthalmology, but in general surely it is more satisfying to be the man in charge than to be the man called in. To have to stay and see the job through is an exacting but a wholesome discipline, seldom imposed on the consultant, and though, heaven knows, I have been and shall again be thankful to share responsibility, I still wish first to accept it.

For these and kindred reasons I was a willing enough candidate for general practice, but not too well equipped. Apart from things forgotten, there were the "special departments." The year 1915, which should have gone to these, went to the war, and it has never been possib!e to retrieve those lost months. I sometimes wonder if either the student or his teachers always understand that it is the candidate for general practice who most needs pregraduate instruction in these departments. The embryo specialist can wait.

\section{Developing a Practice}

To return to the story. It was strange to come back from the world of the Western Front to the world of England. We found a country licking its wounds and tearing off its illusions and supposed illusions till it came near to stripping itself spiritually naked, but universal regulation had not set in and the medical profession, collectively and individually, enjoyed a glorious, almost an absolute, freedom.

My mother hospital was very kind-welcomed me back, taught me, and gave me work according to my needs, first whole-time and then part-time. Examiners also seemed friendly. To cut loose altogether from hospitals appeared less and less desirable, yet if I entered an established practice it seemed almost inevitable. I looked half-heartedly at practices,. feeling distinctly "choosy." A good solid country doctor looked at me and thought I hadn't the physique for the hard work-I do not know if he was right or not. The end of the matter was that I sat down in a part of London where it was pleasant to live and there happened to be a house and where one more doctor could not matter to the many established practitioners. I joined the London panel.

I filled my days with part-time work away from home, leaving only little gaps in which I could see a patient if anyone asked me to do so. The work was at first chiefly hospital work, some paid, some honorary-and it continued, in one form or another, for many years. Parttime work has included an infant welfare clinic, pensions boards, recruiting boards, and work in the school medical service. Patients came very slowly, almost always - then and ever since-urged or sent by some friendly medical man, occasionally by a friendly patient, almost never " out of the street," and very seldom, so far as I know, detached from any neighbouring practitioner.

In the fullness of time there was something that might be called a practice, and while it was growing I was never idle or unemployed. Practice and "extramural" work reciprocated in every way. I am sure that ideally every practitioner should work also at a hospital, clinic, or school, and vice versa. It is hard to know whether the clinic doctor or the family doctor has the more to learn by seeing the other man's "material" and facing his clinical problems.

\section{Deductions}

So much for "how I began." What are the deductions? I seem to myself to have exploded several zealously propagated myths about entry into practice in the bad old days. Such was the tolerance and friendliness of doctors, such the flexibility of the medical "setup" in London thirty to twenty years ago, that there 
was no difficulty in doing what I have described. I did not borrow money, plunge into debt, or live in grinding poverty ; I did not separate myself from hospitals or abandon their clinical standards; I never sat in a consulting-room twiddling my thumbs; I entered into no cut-throat competition with my medical neighbours ; competitors of course we are, to the great advantage of our patients, but there is no cutting of throats, and if there is jealousy or hostility it is marvellous how we disguise it. To judge by behaviour we are friends.

I should like here to explode one more myth-namely, that in private practice one must sell one's integrity to any well-to-do patient who covets it. Sooner or later almost everyone doing anything worth doing is offered a price for his or her soul. A medical man is no exception, but he is not in the least bound to accept the offer, which, incidentally, comes at least as often and as persuasively from a public body as from a patient.

\section{Rewards of Practice}

The chief reward, in my experience, is the clinical work - diagnosis, prognosis, and treatment. It is exceedingly difficult, but not impossibly so, always new, entirely fascinating. There is no danger whatever of the art's dwindling to an exact science. Patients, whether they know it or not, continue to need us badly; neither hygienists nor teams of specialists can take our place. Intrinsically general practice, even if single-handed, is not outmoded-granted, that is, a proper command of ancillary, specialized, and institutional resources. Our present troubles are extrinsic and, in a sense, accidental. The other half of the Hippocratic art-winning and keeping the patient's confidence, subduing, influencing, or outflanking his circumstances, inducing him and his friends to co-operate for his good-is even more difficult than the clinical part. There is no escaping it, but I imagine we mostly find it far the less fascinating and rewarding portion, and some dislike it so much that they take shelter in institutions where it is relatively avoidable.

The intending practitioner should recognize that patients, their friends, and their circumstances will be his care no less than their diseases. It is probably a mistake to hope that one's chief reward will be in doing good to one's fellow men and receiving their well-earned thanks. Our fellow men like to have pain relieved, most of them still wish to live, but many are not prepared to face the implications and responsibilities of being quite well. The gratitude and the ingratitude we receive have often small relation to our deserts. Trying to keep people well is a hard and not seldom an ungrateful task.

By and large I think we have failed as a profession to make people understand what we are for. Very many are blind to our problems, difficulties, and ways of thought, and are equally mistaken concerning our knowledge and powers on the one hand and our ignorances and impotences on the other. Much of this misconception is our own fault. If we could set it right perhaps we should, as a profession and as individual doctors, get a fairer deal.

The British Journal of Tuberculosis (Festival Number) quotes this extract from Pliny”s Natural History: "The cure for phthisis is affected by taking a wolf's liver boiled in wine; the brain of a sow which has been fed upon herbs; or the flesh of a she-ass, eaten with the broth; the last more in particular being the one that is employed by the people of Achaia. Smoke of dried cow-dung inhaled through a reed is remarkably good for phthisis."

\section{THE COUNTRY DOCTOR}

BY

\author{
G. O. BARBER, M.B., B.Chir. \\ Great Dunmow, Essex
}

"There is a providence that shapes our ends, rough hew them how we will," muttered the surgeon as he demonstrated circumcision at the children's hospital during my first house appointment. This misquotation applied equally to my entry into general practice.

The scene was lunch-time in the board room some months later. The medical superintendent looked up from a letter and said, "Who can go down into the country to-morrow to look at a practice?" As everyone else seemed to be well on the road to Harley Street, the finger inexorably pinned down myself, in spite of my protests that I was going shortly for an interview to the Malay Medical Service. "We cannot let the hospital down: someone must at any rate go and look, please. It will give you a nice outing, and a glimpse of a country practice." Next day found me in a strange bit of England. From the station a smart but very old car took me to a large Georgian house right in the middle of a narrow main street of a small town. Inside was fumed oak furniture, a vast sideboard covered with silver plate, curtains of plush and lace, and a general semireligious gloom. The old man and his wife were charming, and obviously he had not long to live. He was trying to decide whether I would be the right person to leave in charge of the community which he had looked after for 40 years.

He took me down to the surgery where he had worked all his life, and I found a dingy little room papered in black with pale green stripes. Ivy climbed in at the window, and damp, mildew, and dirt contended with unopened samples and periodicals. There was no running water, and a dim naked gas jet for light. In the dispensary the bottles stood three deep, coated with dust and with labels which were strange even when I could decipher them. Pride of place was given to a large bowl full of leeches (later on one escaped, and my wife kept clear for weeks afterwards). At the end of the day I said polite good-byes. We had a good laugh when I arrived back in hospital, but I was haunted by the old doctor's pathetic hope that I would after all decide to take the practice.

\section{A Challenge}

Aspiring consultants are advised to keep their emotions in cold storage, but the purchase of a practice allowed a young general practitioner to marry at once, with an assured income. This urge to marry had decided many of my friends, and my turn came simultaneously with the visit I have described. And, apart from the charm of the genuine country, there seemed to be a challenge in the very antiquity of the set-up. Here was something to get one's teeth into, to be able to start almost from the beginning to build up a modern practice.

It has been fun. Everyone thinks his work has been hard, and country practice is no exception, but there was always the excitement of introducing each innovation. Running water was the first, for on my arrival the old doctor used eagerly to await my evening visit, and his first question was, "How many barrels to-day?" An odd question from the family doctor, but 